\title{
Loan Securitization in China's Financial Reform - Based on Evidence from Thirty-five Listed Banks in China
}

\author{
Fang Wang \\ Beijing National Accounting Institute, Beijing 101312, China \\ Email: wangf@mail.nai.edu.cn
}

\begin{abstract}
This paper studies loan securitization in China's financial reform. By using Logit and Tobit model to study 35 Chinese listed commercial bank's data from 2012 to 2019, the author employs the factor analysis to summarize the information from some financial indicators that reveals banks' securitization determinants. A sensitive analysis and a credit-deposit relationship estimation are also conducted to examine the impacts of loan securitization. It is found that determinants of China's banks' securitization include cost advantage exploitation and performance promotion. The incentive of risk transfer involves risks from stock market rather than non-performing loan. There is little evidence that loan securitization improves the income structure of banks and the investment efficiency of financial market. Moreover, the credit-deposit relationship of securitized banks is improved. The paper concludes that China's loan securitization market welcomes large banks with lower risk rather than small banks. Default risks of banks themselves rather than that of loan customers affect bank's securitization decision more. Safe and high-yield spread business is still the best investment of loan securitization proceeds. The loan securitization market should be developed continuously and rapidly, which is of great implications to China's financial reform.
\end{abstract}

Keywords: loan securitization, factor analysis, China's financial reform, Chinese commercial banks

\section{Introduction}

\subsection{Problem statement}

Asset securitization (Asset-backed Securitization, ABS) in China began in 2005, but grew slowly and was suspended in 2008 due to the US subprime mortgage crisis. In May 2012, China restarted its asset securitization business with the Central bank and the China Banking Regulatory Commission (CBRC) stressing the importance of loan securitization in the market-oriented reform of China's banking industry. In 2014, the CBRC launched the filing system, and the issuance speed of loan securitization was greatly accelerated. With the introduction of the filing system, ABS business has been changed from CBRC's prior approval to CFIA(China Fund Industry Association)'s prior registration and post event selfdiscipline management. The regulatory authorities no longer require commercial banks to open the "asset package" review, but to adopt the negative list management. The importance of the filing system is that it simplifies the issuing process of loan securitization, reducing the issuing time and making the issuing process easier. However, the government has not relaxed the regulatory caliber for small banks to issue loan securitization, and the loan securitization market does not welcome small banks with higher risks. As shown in Figure 1 and Table1, in 2014, the annual growth rate of ABS issuance in the inter-bank market reached $1018.88 \%$. However, the growth rate began to decline after 2014 , evidenced by lower growth rates in 2015 of $43.85 \%$ and $-3.64 \%$ in 2016 . Although the growth rate of issuance slows down, the total amount of issuance is rising. By the end of 2019, the total amount of loan securitization issuance in China was 3,710,180 million RMB. What is the decisive factor for the development of China's loan securitization market? Is it driven by policies or the demand of banks themselves? It is of great significance to the development of the asset securitization market, especially for market regulators, to study and understand the underlying reasons behind the phenomenon of accelerating and decelerating issuances within the loan securitization market. More importantly, as an important financial tool for supply-side structural reform, has China's asset securitization played a role in improving the income structure of banks and the efficiency of the financial market? 


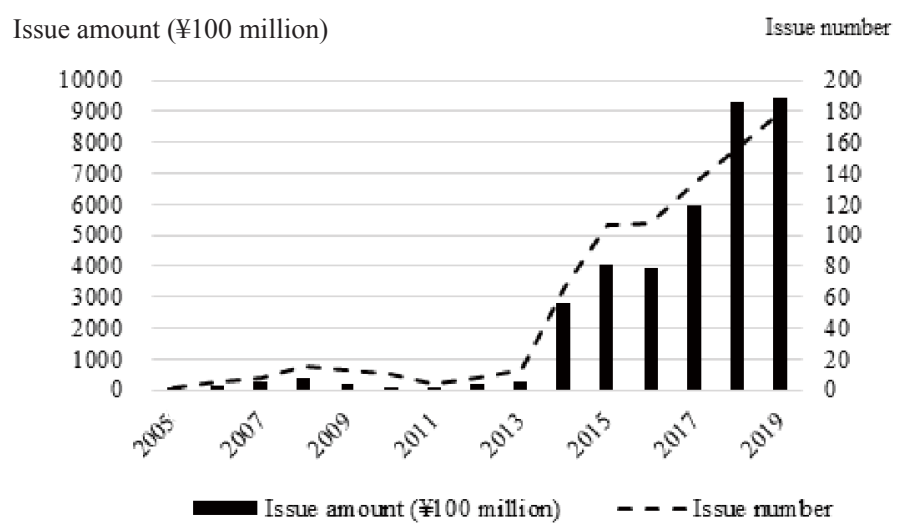

Figure 1. Statistical chart of the issuance of inter-bank asset securitization from 2005 to 2019

Source: WIND; Note: The issuance scale and quantity of China's credit asset-backed securities are scaled to the left and right axes respectively.)

Table 1. The issuance of inter-bank asset securitization from 2005 to 2019

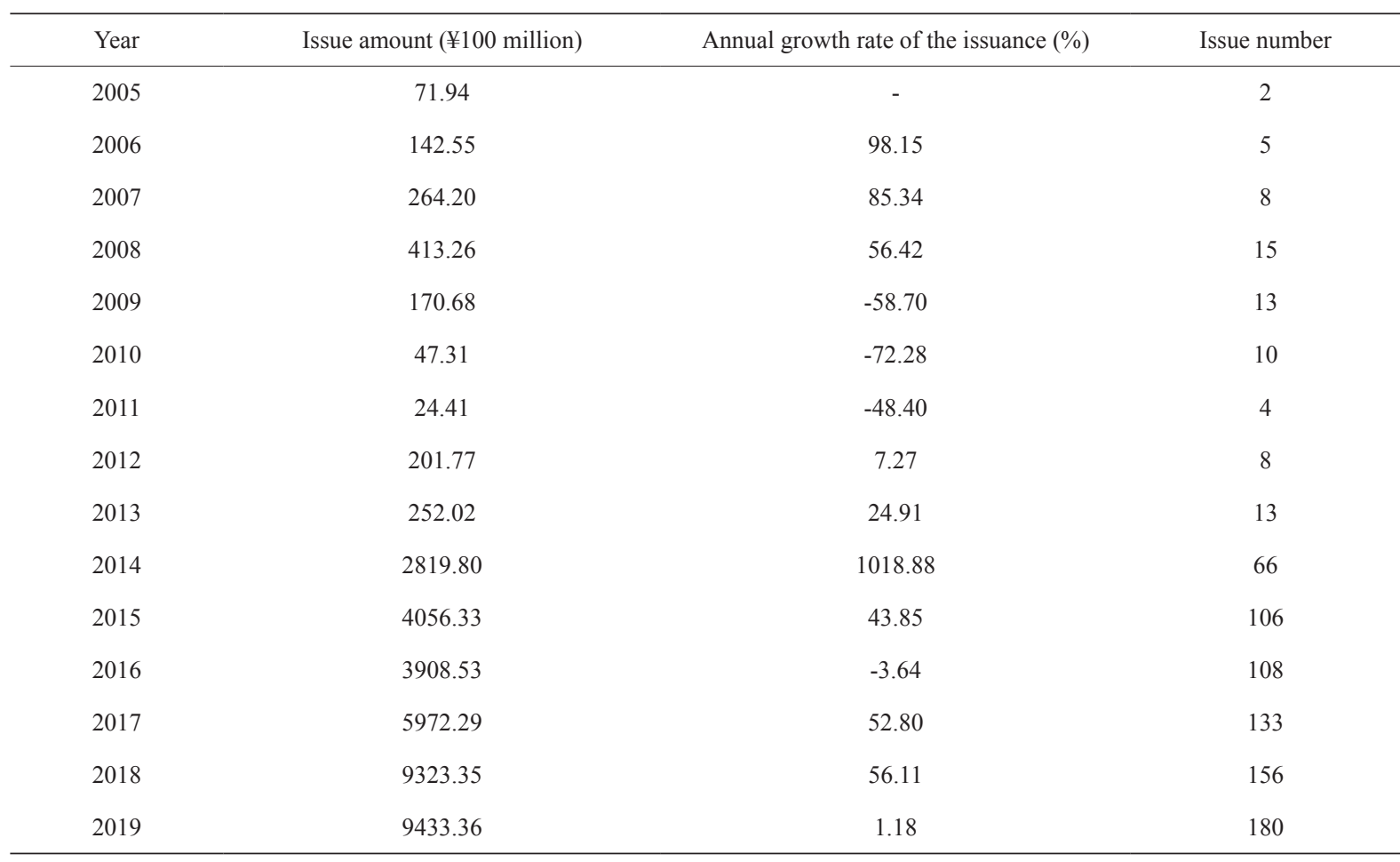

Sources: CNABS

Greenbaum and Thakor (1987) believe that loan securitization is an alternative to bank debt financing and establish a model of determinants of loan securitization. DeMarzo (2005) shows that packaging loans into pools and subsequently selling them in layers could increase the value of loans, emphasizing the benefits of loan securitization to banks. Guo and $\mathrm{Wu}$ (2014) establish a risk-based asset selection model and believe that risk management is the main driver behind the loan securitization of commercial banks. As for empirical research, Minton et al. (2004) argue that the determinants of loan securitization are regulatory arbitrage and profitability promotion. Martin-Oliver and Saurina (2007) believe that the reasons for loan securitization are liquidity demand, risk transfer and profitability promotion demand. Bensalah and Fedhila (2016) find that among all the research literatures on loan securitization, liquidity demand, risk transfer, regulatory arbitrage and profitability promotion are cited the most frequently. Zhang et al.(2018) propose a cost-benefit analysis framework, and empirically examine five determinants of loan securitization of Chinese commercial banks. It concludes 
that large state-owned commercial banks with high ratings are welcomed into China's loan securitization market, while small and medium-sized banks with poor asset quality are not welcome.

\subsection{Background of loan securitization of commercial banks in China}

From a capital cost perspective, when the comprehensive financing cost of bonds and stocks are high, commercial banks will choose loan securitization. Table 2 is a simplified commercial bank balance sheet. Issuing bonds reflects the securitization of "liabilities", which increases the leverage of commercial banks, and the use of funds is limited by creditors. Issuing stock is the securitization of "owner's equity". Based on the current situation of China's stock market, the waiting period for stock financing is long, the comprehensive capital cost is high, and new shares will dilute the control of major shareholders of the company. Issuing asset-backed securities is the securitization of "assets" on the left side of the bank's balance sheet. The use of ABS proceeds is not limited by investors, nor will it increase the bank's asset liability ratio, and the comprehensive capital cost is low.

Table 2. Commercial bank's securitization

\begin{tabular}{ccc}
\hline Assets & Liabilities & Owner's equity \\
\hline Loan & Deposit & Capital \\
$\downarrow$ & $\downarrow$ & $\downarrow$ \\
Loan-backed security & Bond & Stock \\
\hline
\end{tabular}

From the perspective of profitability, shadow banks in China's financial system have developed rapidly in recent years. The high yields of online P2P financial products have had a significant impact on the interest margin profit model of banks. Commercial banks have had to look for new profit growth opportunities through financial innovation. Asset securitization represents one of these opportunities, allowing banks to sell low-profit loans and invest in high-profit projects, thus improving business performance.

From the perspective of regulatory arbitrage, when commercial banks need to whitewash their balance sheets to meet regulatory requirements, they will choose loan securitization. At present, the main regulatory indicators of China's commercial banks include the capital adequacy ratio (core capital adequacy ratio is greater than or equal to $8 \%$ ), liquidity ratio (greater than or equal to $100 \%$ ), loan deposit ratio (less than or equal to $75 \%$ ) etc (Source: CBIRC website.). When commercial banks fail to meet these regulatory indicators, they are punished by regulators, and the stability of banks will be questioned by the financial market. Loan securitization of commercial banks convert loans on the balance sheet into cash, reducing the loan balance required to meet the loan deposit ratio whilst supplementing capital to improve the capital adequacy ratio. Furthermore, loan securitization allows commercial banks to increase their current assets, ensuring that the liquidity ratio is in line with regulatory requirements.

There is currently a great opportunity to develop China's asset securitization market. China is a country mainly engaged in indirect financing. On average, the balance of bank loans account for around $80 \%$ of the total amount of social financing. The total amount of social financing is the annual total amount of new financing of the financial industry to the real economy. It includes both the indirect financing of the banking system and the direct financing of bonds and stocks in the capital market. The scale of bond issuance accounts for about $10 \%$, and the amount of stock issuance accounts for about $4 \%$. As a supplement to traditional financing means, asset-backed securities account for a small proportion, representing only $2.75 \%$ of the total amount of social financing from 2014 to 2019, as shown in Figure 2.

In 2009 , to cope with the global economic recession caused by the US subprime mortgage crisis, the Chinese government launched a "four trillion" (RMB) economic stimulus plan. The implementation of the plan has led to overinvestment in China's economy, the accumulation of non-performing loans of commercial banks, and the rapid growth of shadow banks in the financial system. A large number of loans are deposited on the balance sheet of commercial banks, constituting a risk to these banks and the broader financial system. Therefore, in 2016, the Chinese government put forward supply-side reform measures, namely "destocking, capacity reduction, deleveraging, cost reduction, and strengthening weak links". Asset securitization is one of the components of supply-side reform. For commercial banks, loan securitization can ease the dependence of loans on deposits and improve non-interest income so as to realize the "asset light strategy" through "off-balance sheet" financing, thus transferring high-risk and low-income loans, and investing high-quality assets to enhance their profitability. 


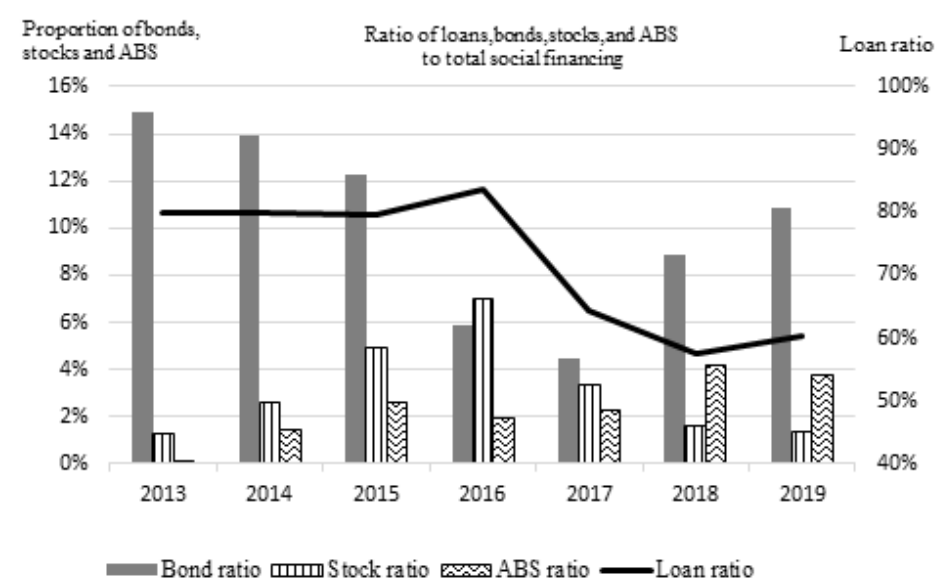

Figure 2. Proportion of loans, bonds, stocks and ABS in total social financing in China's financial market

Source: WIND

The development of the asset securitization market has important policy implications to China's "supply-side structural reform". The logical road map for China's financial reform is shown in Figure 3.

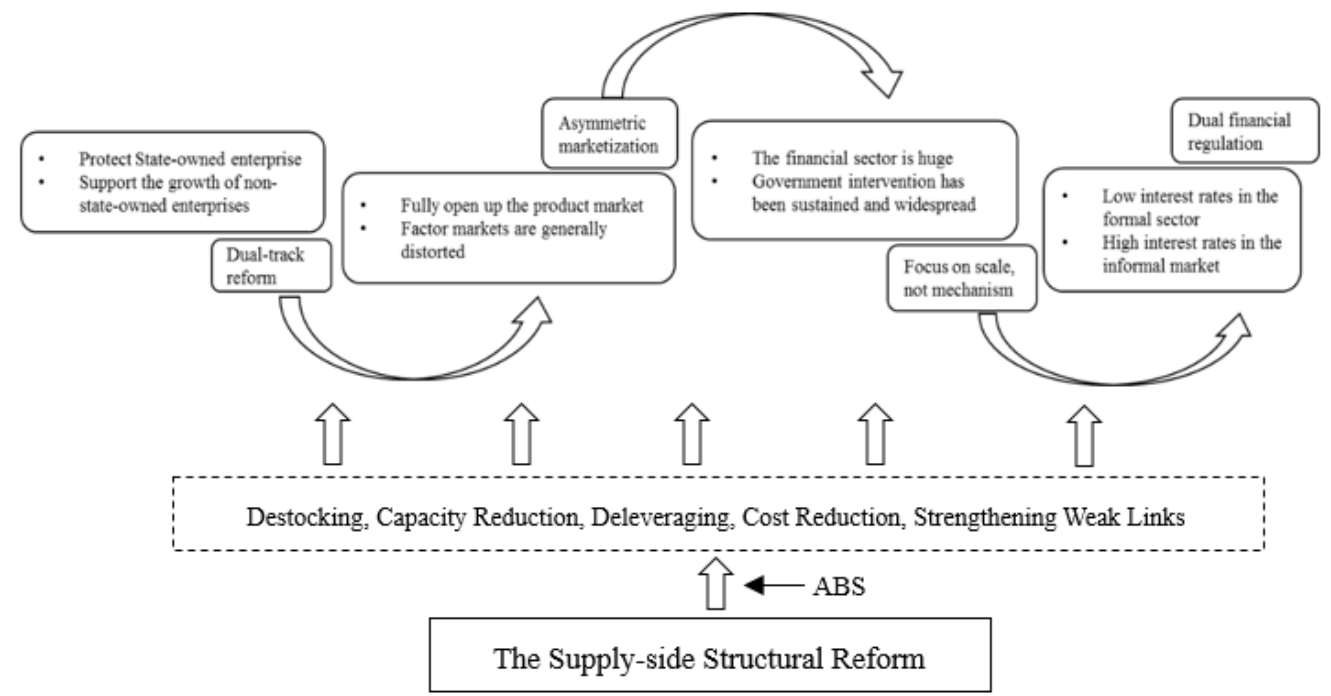

Figure 3. The logical road map for China's financial reform

\section{Theoretical framework and research methods}

\subsection{Theoretical framework}

\subsubsection{The motivation of bank's loan securitization}

Loan securitization is an alternative to bank debt financing (Greenbaum and Thakor, 1987). Packaging loans into pools and subsequently selling them in layers could increase the value of loans (DeMarzo, 2005). Risk management of selling loans is the main driver behind loan securitization (Guo and Wu, 2014). The determinants of loan securitization are regulatory arbitrage, liquidity demand, risk transfer, profitability promotion demand and cost advantage exploitation (Minton et al., 2004; Martin-Oliver and Saurina, 2007; Bensalah and Fedhila, 2016; Zhang et al., 2018).

\subsubsection{The implication of loan securitization to China's financial reform}

This paper takes "the logical road map for China's financial reform" as a theoretical framework to study "the implication of loan securitization to China's financial reform”. As shown in Figure 3.

In China's 40 years of reform and development, fixed asset investment has been the main driving force of economic growth. The financial system that has successfully supported factor driven growth in the past is now in urgent need of 
transformation. In recent years, the investment efficiency indicator ICOR (marginal capital output rate) has increased significantly (from $3.5 \%$ in 1985 to $15 \%$ in 2017) indicating that China's capital or financial efficiency is declining. The result of the decline of financial efficiency is the increase of financial risk. Now, preventing systemic financial risks has become one of the major reform goals of the government (Huang Yiping,et al., 2018). Securitization can help reduce the systematic financial risk of the banking system by converting long-term infrastructure loans into more effective financial assets.

Through asset securitization, commercial banks convert illiquid loans into cash and then invest in other non-credit financial assets in order to obtain no-interest income (NIR). Asset securitization helps commercial banks reduce the proportion of credit assets so that they not only use credit instruments, but also rely on intermediate business operations, such as participating in the bond markets (treasury bonds, corporate bonds, asset-backed securities, etc.) (Wu Qing, 1999; Shen Bingxi, 2006).

Asset securitization can also change the dependence of commercial banks on deposits and realize credit expansion. Excessive dependence on deposit financing will leave part of the credit demand unsatisfied, thus reducing economic efficiency. As a new source of capital for commercial banks, securitization can relax the tension between deposits and credit growth (Almazan, et al., 2015).

\subsection{Research methods}

\subsubsection{Previous research}

The research methods of this paper follow Afinito and Tagliaferri (2010) and Zhang et al. (2018), see Table 3. Afinito and Tagliaferri (2010) study the four determinants of loan securitization in 138 commercial banks in Italy during the period of 2000-2006 using logistic panel regression. Zhang et al. (2018) take 155 commercial banks in China as samples from 2012 to 2017 and used factor analysis, logistic and Tobit panel regression methods to study five determinants of loan securitization of commercial banks.

Table 3. Previous research

\begin{tabular}{|c|c|c|c|}
\hline & Affinito and Tagliaferri (2010) & Zhang et al. (2018) & This study \\
\hline Object of analysis & Italian banks & Chinese banks & Chinese banks \\
\hline Analysis period & $2000-2006$ & $2012-2017$ & $2012-2019$ \\
\hline Data sources & $\begin{array}{l}\text { Bank of Italy's Annual Report, the Bank } \\
\text { of Italy's accounting supervisory reports } \\
\text { and the Italian Central Credit Register }\end{array}$ & $\begin{array}{l}\text { CBRC annual report, Orbis Bank } \\
\text { Focus, China Securitization } \\
\text { Analytics, WIND }\end{array}$ & $\begin{array}{l}\text { WIND, China Securitization } \\
\text { Analytics }\end{array}$ \\
\hline Number of firms & 138 & 155 & 35 \\
\hline $\begin{array}{l}\text { Research } \\
\text { hypothesis }\end{array}$ & $\begin{array}{l}\text { Four main determinants : new sources } \\
\text { funding, credit risk transfer, profit } \\
\text { opportunities; the role of capital. }\end{array}$ & $\begin{array}{l}\text { Five main determinants : liquidity } \\
\text { demand, regulatory arbitrage, } \\
\text { profitability promotion, risk transfer, } \\
\text { cost advantage exploitation. }\end{array}$ & $\begin{array}{l}\text { Five main determinants : liquidity } \\
\text { demand, regulatory arbitrage, } \\
\text { profitability promotion, risk transfer, } \\
\text { cost advantage exploitation. }\end{array}$ \\
\hline Securitization index & $\begin{array}{l}\text { (1) ABS dummy } \\
\text { (2) How much to securitize }\end{array}$ & $\begin{array}{l}\text { (1) ABS dummy } \\
\text { (2) How much to securitize }\end{array}$ & $\begin{array}{l}\text { (1) ABS dummy } \\
\text { (2) How much to securitize }\end{array}$ \\
\hline Model & $\begin{array}{l}\text { Logit panel regressions: } \\
\text { Log(ABS Yit=1) = f(Xit; Zit) }\end{array}$ & $\begin{array}{l}\text { (1) Factor analysis } \\
\text { (2) Logistic panel regressions } \\
\text { (3) Tobit panel regressions }\end{array}$ & $\begin{array}{l}\text { (1) Factor analysis } \\
\text { (2) Logistic panel regressions } \\
\text { (3) Tobit panel regressions }\end{array}$ \\
\hline \multicolumn{4}{|l|}{ Determinants: } \\
\hline Funding & - & l & / \\
\hline Risk transfer & + & / & / \\
\hline Profit opportunities & - & / & - \\
\hline $\begin{array}{l}\text { Capital adequacy } \\
\text { ratio }\end{array}$ & - & - & / \\
\hline $\begin{array}{l}\text { Cost advantage } \\
\text { exploitation }\end{array}$ & / & + & + \\
\hline \multicolumn{4}{|l|}{ Implications: } \\
\hline Z-score & & & - \\
\hline $\mathrm{DtD}$ & & & - \\
\hline NIR & & & - \\
\hline ICOR & & & + \\
\hline Credit and deposit & & & - \\
\hline
\end{tabular}




\subsubsection{Multiple regression model}

In this paper, 35 Chinese commercial banks are used to analyze the five determinants of bank loan securitization from 2012 to 2019. The research model is as follows, see formula (1) and (2).

$$
P\left(\sec _{i, t}=1 \mid F_{i, t-1}\right)=c+\sum_{j=1}^{n} \beta_{j} F_{i, t-1}^{j}+\text { Control }_{i, t-1}+\mu_{i, t}
$$

The probability distribution function on the left of formula (1) is the logistic function. The variable $\sec _{i, t}$ is the explained variable, a dummy variable indicating whether the banks engaged in securitization. $F_{i, t-1}^{j}$ is the explanatory variable, and includes six factors that correspond to five securitization incentives.

$$
\begin{aligned}
& y_{i, t}^{*}=a+\sum_{j=1}^{7} \beta_{j} F_{i, t-1}^{j}+\text { Control }_{i, t-1}+\varepsilon_{i, t} \\
& y_{i, t}= \begin{cases}y_{i, t}^{*} & y_{i, t}^{*}>0 \\
0 & \text { others }\end{cases}
\end{aligned}
$$

Formula (2) is a Tobit regression model. It is used to test whether the common factor can further explain the amount of loan securitization. The explained variable $y_{i, t}$ is SEMT, a continuous variable.

\subsubsection{Hypotheses}

(1) Based on previous literature, this study proposes five determinants of loan securitization in China's commercial banks.

(1) Liquidity demand

(2) Regulatory arbitrage

(3) Profitability promotion

(4) Risk transfer

(5) Cost advantage exploitation

(2) Based on "the logical road map for China's financial reform", this study proposes three implications of loan securitization to China's financial reform.

(1) The financial efficiency (ICOR)

(2) The non-interest income of banks(NIR)

(3) The reliance between credits and deposits

\subsubsection{Possible contributions}

Compared with previous studies (see Table 3), the data of Afinito and Tagliaferri (2010) consists of commercial banks in Italy, and the comparability of the conclusion is low. Most of the samples of Zhang et al., (2018) are non-listed banks, and the data is unaudited and derived from the non-public capital market, reducing the credibility of the analysis. In addition, each bank contains missing data which the author has filled in using linear interpolation, subjecting it to a high degree of error.

This paper aims to contribute to the existing literature in six ways. First, the reliability of data is higher. This paper uses open market data derived from the annual reports of 35 listed Chinese banks, audited by certified public accountants, with high reliability. Second, the availability of data is better. The data used in this paper is from open market channels where availability is high. The variables used in this paper are determined based on the availability of data (for the list of replacement variables, see Table 4). As shown in Table 4, the data underlying the ROL and LLR in Zhang et al., (2018) are not disclosed. As such, CIR and PC are used instead in this paper. Third, this research supplements the data used by Zhang et al. (2018) and adds 2018-2019 data in order to test the latest changes in China's loan securitization market. Fourth, this study uses the Robustness test of substituting risk variables (Z-score and DtD) to further explore the risk transfer motivation of commercial banks' when engaging in loan securitization. Fifth, this paper adds two variables in order to do a sensitivity analysis to estimate the implication of loan securitization to China's financial reform. Sixth, the research examines the implications of loan securitization on the relationship between credit and deposit.

Table 4. Substitution of variables

\begin{tabular}{ccc}
\hline Incentive & Variables: In this paper & Variables: In Zhang et al.(2018) \\
\hline $\begin{array}{c}\text { Profitability } \\
\text { promotion }\end{array}$ & $\begin{array}{c}\mathrm{CIR}=\text { Cost-income ratio=Cost } / \text { Income } \\
\text { = Operating expenses } / \text { revenue }\end{array}$ & $\begin{array}{c}\text { ROL=Return on loans } \\
\text { =Pretax profit/Average annual gross loans } \\
\text { Risk transfer }\end{array}$ \\
$\begin{array}{c}\mathrm{PC}=\text { Loan loss provision ratio }= \\
\text { Loan loss provisions/Loan(Subprime+doubtful+loss) }\end{array}$ & $\begin{array}{c}\text { Loan loss provision ratio }= \\
\text { provisions/Total loan }\end{array}$ \\
\hline
\end{tabular}

The author gives five different conclusions. First, that the incentives of commercial banks to pursue loan securitization arise from profitability promotion and cost advantage exploitation, and thus no longer regulatory arbitrage. Second, 
listed banks pay more attention to their overall risk from the stock market rather than non-performing loans. Third, the loan securitization has effectively lowered the dependence of credits on deposits. Fourth, the income from securitization continues to be invested in new loan business rather than to increase non-interest income. Fifth, little evidence is found that loan securitization improves the investment efficiency of China's financial market.

\section{Data}

\subsection{Data source}

Raw data is collected from WIND and CSMAR from 2012 to 2019. Thirty-five Chinese listed banks are examined, as shown in Table 5. According to the bank classification standard of CBIRC, there were six large state-controlled commercial banks (No.1 to No.6), nine national joint-stock commercial banks (No.7 to No.15), and twenty regional commercial banks (No.16 to No.35).

Table 5. Thirty five listed banks in China

\begin{tabular}{|c|c|c|c|c|}
\hline Serial Number & Bank name & Securities code & Listing place & Bank type \\
\hline 1 & INDUSTRIAL AND COMMERCIAL BANK OF CHINA & 601398 & SH & State-controlled \\
\hline 2 & AGRICULTURAL BANK OF CHINA & 601288 & $\mathrm{SH}$ & State-controlled \\
\hline 3 & BANK OF CHINA & 601988 & SH & State-controlled \\
\hline 4 & CHINA CONSTRUCTION BANK & 601939 & SH & State-controlled \\
\hline 5 & BANK OF COMMUNICATIONS & 601328 & $\mathrm{SH}$ & State-controlled \\
\hline 6 & POSTAL SAVINGS BANK OF CHINA & 01658 & HK & State-controlled \\
\hline 7 & CHINA MERCHANTS BANK & 600036 & $\mathrm{SH}$ & National joint-stock \\
\hline 8 & SHANGHAI PUDONG DEVELOPMENT BANK & 600000 & SH & National joint-stock \\
\hline 9 & CHINA CITIC BANK & 601998 & SH & National joint-stock \\
\hline 10 & CHINA EVERBRIGHT BANK & 601818 & $\mathrm{SH}$ & National joint-stock \\
\hline 11 & HUA XIA BANK & 600015 & SH & National joint-stock \\
\hline 12 & CHINA MINSHENG BANK & 600016 & SH & National joint-stock \\
\hline 13 & INDUSTRIAL BANK CO.,LTD. & 601166 & SH & National joint-stock \\
\hline 14 & PING AN BANK. & 000001 & SZ & National joint-stock \\
\hline 15 & CHINA ZHESHANG BANK & 02016 & $\mathrm{HK}$ & National joint-stock \\
\hline 16 & BANK OF BEIJING & 601169 & $\mathrm{SH}$ & Regional \\
\hline 17 & CHANGSHU RURAL COMMERCIAL BANK & 601128 & SH & Regional \\
\hline 18 & BANK OF CHONGQING & 01963 & $\mathrm{HK}$ & Regional \\
\hline 19 & BANK OF GUIYANG & 601997 & $\mathrm{SH}$ & Regional \\
\hline 20 & HARBIN BANK & 06138 & HK & Regional \\
\hline 21 & BANK OF HANGZHOU & 600926 & SH & Regional \\
\hline 22 & HUISHANG BANK & 03698 & HK & Regional \\
\hline 23 & BANK OF JIANGSU & 600919 & SH & Regional \\
\hline 24 & JIANGYIN RURAL COMMERCIAL BANK & 002807 & SZ & Regional \\
\hline 25 & BANK OF JINZHOU & 00416 & HK & Regional \\
\hline 26 & BANK OF NANJING & 601009 & $\mathrm{SH}$ & Regional \\
\hline 27 & BANK OF NINGBO & 002142 & $\mathrm{SZ}$ & Regional \\
\hline 28 & BANK OF QINGDAO & 03866 & HK & Regional \\
\hline 29 & BANK OF SHANGHAI & 601229 & SH & Regional \\
\hline 30 & SHENGJING BANK & 02066 & HK & Regional \\
\hline 31 & WUXI RURAL COMMERCIAL BANK & 600908 & SH & Regional \\
\hline 32 & WUJIANG RURAL COMMERCIAL BANK & 603323 & SH & Regional \\
\hline 33 & RURAL COMMERCIAL BANK OF ZHANGJIAGANG & 002839 & SZ & Regional \\
\hline 34 & BANK OF ZHENGZHOU & 06196 & HK & Regional \\
\hline 35 & GUANGZHOU RURAL COMMERCIAL BANK & 01551 & HK & Regional \\
\hline
\end{tabular}




\subsection{Data processing}

(1) Banks with limited data available were eliminated;

(2) The characteristic variables of commercial banks are one-year lagged annual data from 2012 to 2019;

(3) The impact of different years was considered;

(4) Different companies are clustered to consider the standard error within the group.

\subsection{Variables selection and descriptions}

The dependent variable for the Logit regression is a binary variable . During the observation period, if the commercial bank issues a securitized loan, the value is 1 , otherwise it is 0 . The dependent variable for the Tobit regression is the issue amount of loan securitization. Eight original explanatory variables were selected according to previous literature and divided into five independent components (see Table 6 for a description of the variables).

Table 6. Variables descriptions

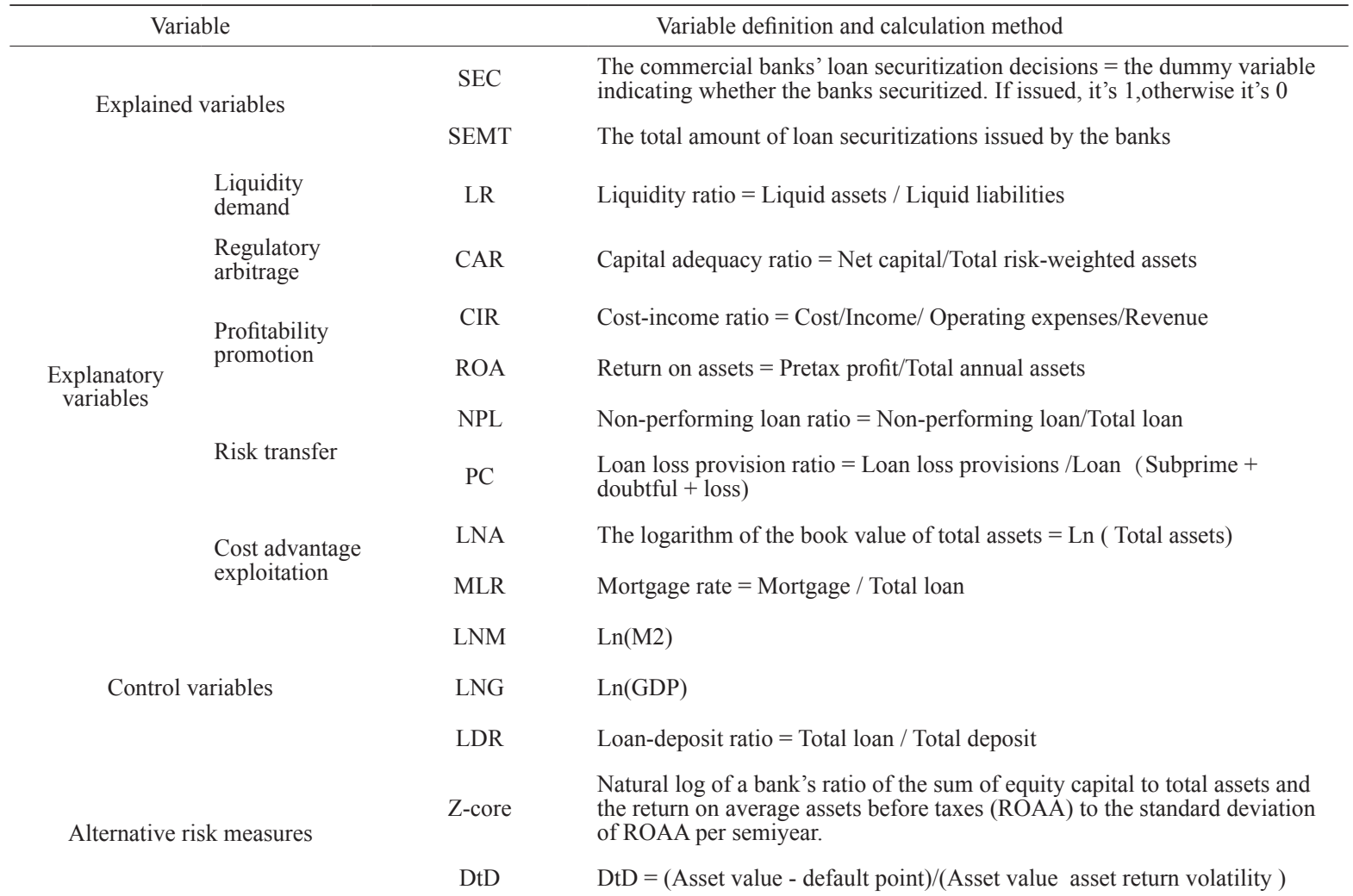

Implication of loan securitization to financial reform

$\begin{array}{ccl}\begin{array}{c}\text { Regulatory and institutional } \\ \text { environment }\end{array} & \text { NIR } & \text { Non-interest income = Operating income - Interest income } \\ & \text { ICOR } & \begin{array}{l}\text { Incremental capital output ratio = I/ } \triangle \text { GDP }=\text { Gross fixed capital formation / } \\ \text { GDP increment }\end{array} \\ \text { The reliance on deposit and loan } & \text { Credit-growth } & \text { Current loan increment / Opening loan balance } \\ & \text { Deposit-growth } & \text { Current deposit increment / Opening deposit balance }\end{array}$

The liquidity demand incentive depends on the liquidity ratio (LR) and states that commercial banks will transform illiquid loans into liquid assets through securitization (Almazan et al., 2015). A low liquidity ratio implies that the current assets of commercial banks is not sufficient to match their current liabilities, improving the liquidity demand incentive of commercial banks.

The regulatory arbitrage incentive is represented by the capital adequacy ratio (CAR). Regulation arbitrage occurs when commercial banks transform high-risk-weighted loans into low-risk-weighted securities through securitization in order to release capital. Calem and LaCour-Little (2004) and Ambrose et al. (2005) all find evidence to support this theory. A lower capital adequacy ratio will stimulate commercial banks to supplement capital, reduce risk weighted assets, and improve regulatory arbitrage incentives through loan securitization. 
The incentive of profitability promotion depends on the cost-income ratio (CIR) and return on assets (ROA). CIR = Cost-income ratio $=$ Cost/Income $=$ Operating expenses/Revenue. In this paper, "operating expenses" do not include the "impairment losses of assets". Profitability promotion occurs when commercial banks optimize their loan structure through securitization and convert low-return loans into high-return loans to improve their performance (Cardone Riportella et al., 2010). A higher cost-income ratio and lower return on assets will improve the profitability promotion incentive.

Risk transfer incentive relies on the non-performing loan ratio (NPL) and loan loss provision ratio (PC). Risk transfer entails that commercial banks will sell loans with high default risk through securitization to improve the quality of the assets in their portfolio. Indeed, Agarwal et al., (2012) and DeMarzo and Duffie (1999) find evidence supporting this hypothesis. A higher non-performing loan ratio and lower loan loss provision ratio means that commercial banks have higher default risk, which increases the bank's risk transfer incentive from loan securitization.

The incentive of cost advantage exploitation depends on the mortgage rate (MLR) and natural logarithm of bank assets (LNA). Cost advantage exploitation refers to the demand of commercial banks to reduce the cost of loan securitization by expanding the scale of issuance, also known as "scale economy". The cost of loan securitization includes fixed costs and variable costs. Fixed costs are related to the bank's scale. The larger the bank's scale, the lower the fixed cost of the asset's securities. Variable costs are related to the asset structure of commercial banks. The main assets that commercial banks can securitize are loans. The difficulty and cost of mortgage securitization is less than other forms of loan securitization. The higher the proportion of the mortgage as part of the total loan, the lower variable cost. The higher the asset scale and mortgage rate, the greater the incentive of commercial banks to pursue cost advantage exploitation.

\subsubsection{Variables of alternative risk measures}

Z-score is a multivariate financial formula (Altman, 2000), which is used to measure the financial distress and bankruptcy risk of an enterprise. Because the variable is mostly the financial ratio of the listed company's financial report, it is considered an accounting based measure of a bank's overall risk exposure. A lower Z-score represents a higher bankruptcy risk (Farruggio,C., and Uhde,A., 2015). DtD, distance-to-default, is a market-based measure of a bank's overall risk exposure. It is the difference between the market value of the company's assets and liabilities at a certain time point. It is designed to indicate the number of standard deviations that the bank is away from the default point within a given time horizon. A lower DtD represents a higher default risk (Merton, 1974). The description for the variables Z-score and DtD are shown in Table 6 and the calculation process is in the Appendix.

\subsubsection{Variables of loan securitization implication to financial reform.}

NIR, non-interest income of banks. It is equal to operating income minus interest income. It is mainly the income from intermediary business and consulting and investment activities. In terms of the income structure of banks in China, interest income accounts for nearly $80 \%$ of operating income (Figure 4). However, interest income is greatly affected by interest rate changes and the economic cycle, and the risk of bad loans are high. In recent years, domestic banks have begun to increase investment in non-interest income business, which is relatively stable, safe and usually has higher profit margin.

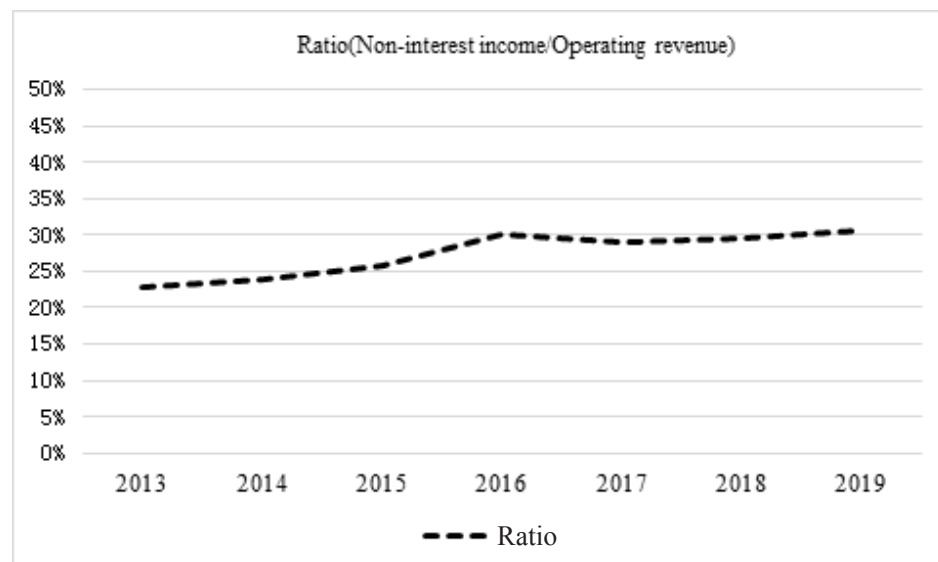

Figure 4. Ratio of the non-interest income to operating revenue of banks

Source: WIND

ICOR, is the marginal capital output rate. ICOR reflects how many units of investment is needed for a unit of GDP growth. Therefore, the larger the marginal capital output rate, the lower the investment efficiency. Conversely, the smaller 
the marginal capital output rate, the higher the investment efficiency.

Table 7 highlights the direction of influence of the aforementioned eight variables on bank loan securitization incentives. Through the analysis of the above variables, we make the following hypotheses. (1) The decrease in liquidity ratio will increase the liquidity incentive of bank securitization. (2) The reduction of the capital adequacy ratio will increase the regulatory arbitrage incentive of bank securitization. (3) The increase of the cost-income ratio will strengthen the incentive of bank performance improvement, whilst the increase in return on assets will weaken the incentive. (4) The increase in the non-performing loan ratio will enhance the risk transfer incentive, whilst the increase in the loan loss provision ratio will diminish the incentive. (5) The increase in bank asset scale and mortgage rates will have a positive impact on the cost advantage exploitation incentive. (6) The decrease of Z-score and DtD will enhance the risk transfer incentive.

Table 7. The statistical characteristics of the original explanatory variables

\begin{tabular}{|c|c|c|c|c|c|c|}
\hline \multirow{2}{*}{ Variable } & \multicolumn{2}{|c|}{ Securitized sample } & \multicolumn{2}{|c|}{ Un-securitized sample } & \multicolumn{2}{|c|}{ Diff } \\
\hline & Mean & Stand error & Mean & Stand error & Mean & Stand error \\
\hline $\mathrm{LR}(-)$ & 48.8439 & 19.1389 & 48.0182 & 22.7805 & +0.8257 & 2.1472 \\
\hline CAR(-) & 12.4543 & 2.9433 & 12.3821 & 2.7527 & +0.0721 & 0.2743 \\
\hline $\operatorname{CIR}(+)$ & 28.3022 & 5.8761 & 28.3004 & 7.3258 & +0.0018 & 0.6632 \\
\hline ROA(-) & 0.9025 & 0.6633 & 1.2552 & 1.1554 & $-0.3526^{* * *}$ & 0.0960 \\
\hline $\mathrm{NPL}(+)$ & 1.3822 & 0.3656 & 1.3688 & 0.7114 & +0.0133 & 0.0585 \\
\hline $\mathrm{PC}(-)$ & 223.1765 & 80.3811 & 243.5114 & 84.6875 & $-20.3349 * *$ & 8.1609 \\
\hline $\operatorname{LNA}(+)$ & 29.0562 & 1.3484 & 27.4000 & 1.4883 & $+1.6562 * * *$ & 0.1404 \\
\hline $\operatorname{MLR}(+)$ & 0.1882 & 0.0608 & 0.1785 & 0.0525 & $+0.0097 *$ & 0.0054 \\
\hline Z-score(-) & 0.1104 & 0.0285 & 0.0929 & 0.0371 & $+0.0175^{* * *}$ & 0.0033 \\
\hline DtD(-) & 39.9969 & 128.9407 & 60.5987 & 54.6729 & $-20.6018^{* *}$ & 10.0821 \\
\hline NIR(-) & 0.2850 & 0.0940 & 0.2007 & 0.1036 & $+0.0843 * * *$ & 0.0109 \\
\hline Credit-growth $(+)$ & 0.1162 & 0.1566 & 0.1424 & 0.1757 & 0.0262 & 0.0168 \\
\hline Deposti-gowth(-) & 127.2698 & 1169.0920 & 0.1903 & 0.2292 & $+127.0794 *$ & 75.4265 \\
\hline
\end{tabular}

Note: $* * * * * *$, indicate confidence levels of $1 \%, 5 \% 10 \%$, under t-test, respectively. The symbol in parentheses after the variable indicates the theoretical hypothesis of the variable's influence direction on the incentives of a bank to pursue loan securitization.

Source: WIND and CSMAR

We also make hypotheses about the direction of loan securitization implication on China's financial reform. (7) The increase of a bank's non-interest income will reduce their tendency to engage in loan securitization. (8) The increase of credit growth will not affect the deposit growth of securitizing banks but will decrease the deposit growth of unsecuritizing banks in contrast.

\section{Statistical analysis}

\subsection{Summary statistics}

Table 7 shows the statistical characteristics of the original explanatory variables. The symbol in parentheses after the variable indicates the theoretical hypothesis of the variable's influence direction on the incentives of a bank to pursue loan securitization. The result shows the means and standard deviations of each proxy variable in two subsamples (securitized and un-securitized), and reflects whether the mean of the two subsamples is significantly different under a t-test. In general, the differences between the sub-samples of securitization and non-securitization are consistent with the results of previous theoretical analyses. However, some variables show unexpected results. The LR and CAR mean of the two sub-samples are not significant, indicating that China's commercial banks may not be securitized for liquidity demand and regulatory 
arbitrage. The difference of the two sub-samples on CIR and NPL is contrary to the theoretical hypothesis, namely that the cost-income ratio and non-performing loan ratio of securitized banks is greater than that of non-securitized banks. A possible explanation for this is that the cost factor and the credit risk factor of NPL are not the primary drivers behind a bank's securitization decision. The cost factor includes the bank's operating cost and the variable cost of securitization.

\subsection{Correlations of variables and factor analysis}

$\mathrm{KMO}$ and Bartlett's tests are used to examine the correlation between variables. The result of the KMO test is 0.504 , which is higher than 0.5 , indicating that the correlation between variables is close to the average value. Bartlett's test value is 254.448 and the confidence level is $0.1 \%$, indicating that there is a correlation between variables. Therefore, the factor analysis method is appropriate for this analysis.

Principal component analysis is used to extract six factors as explanatory variables for regression analysis. The relationship between the six factors and their proxy variables are shown in Table 8. Loadings whose absolute values are greater than 0.5 are highlighted in bold. The economic meaning of each factor is primarily related to variables with a large factor loading. F1 refers to a high loan risk factor, which corresponds to a risk transfer incentive for the variables of NPL and PC. F2 is special for its large loading of ROA. ROA is a proxy variable of the profitability promotion incentive. F3 is called the large scale factor, corresponding to the cost advantage exploitation incentive and the proxy variable is LNA. F4 is called the high cost-to-income ratio factor and corresponds to the profitability promotion incentive and represents the proxy variable CIR. F5 is called the high capital adequacy ratio factor with the large loading variable CAR and represents the incentive of regulatory arbitrage. F6 refers to the high liquidity factor and corresponds to the liquidity demand incentive, its proxy variable is LR. MLR has not been included in the six factors because its loading is less than 0.5. One possible explanation is that China's financial market regulations have focused on the real estate market bubble since 2019 , which has led to a serious decline in the amount of real estate mortgage loans.

Table 8. Factor loading matrix after varimax

\begin{tabular}{|c|c|c|c|c|c|c|}
\hline & $\mathrm{F} 1$ & F2 & F3 & F4 & F5 & F6 \\
\hline CAR & .021 & .029 & .013 & -.035 & .963 & .015 \\
\hline ROA & .136 & .954 & -.004 & -.017 & .053 & -.077 \\
\hline NPL & -.836 & -.191 & -.141 & -.152 & .094 & -.150 \\
\hline PC & .878 & -.026 & -.183 & -.037 & .055 & -.101 \\
\hline
\end{tabular}

Source: WIND and CSMAR, and China Securitization Analysis database

Note: Values with an absolute value greater than 0.5 are shown in bold

\section{Regression analysis}

\subsection{The Logit regression}

Table 9 Column (1) contains the full sample Logit regression result examining the influence of determinant factors on the securitization frequency of commercial banks.

First, the coefficient of factors "High ROA"(-0.4669***) and "Large scale"(LNA, 1.4164***) are significant, and their direction is consistent with the incentive hypotheses of profitability promotion and cost advantage exploitation, indicating that the hypotheses are supported in practice. Banks with large scale assets, and banks with poor profitability tend to carry out loan securitization. Second, the coefficient of other factors, such as "High loan risk"(NPL and PC, 0.2436), "High cost-to-income ratio" (CIR, 0.0260), "High capital adequacy ratio" (CAR,0.1497) and "High liquidity" (LR, 0.2860), are not significant, which means the hypotheses are not supported in practice. The coefficient's direction of factors "High capital adequacy ratio" (CAR) and "High liquidity" (LR) are not in line with the previous hypotheses, indicating 
that Regulatory arbitrage and Liquidity demand are not the influential drivers for loan securitization.

Table 9. Estimation for the determinants of loan securitization

\begin{tabular}{|c|c|c|}
\hline \multirow{2}{*}{ VARIABLES } & (1) & (2) \\
\hline & SEC & SEMT \\
\hline \multirow{2}{*}{ High loan risk } & 0.2436 & 42.7256 \\
\hline & $(0.3142)$ & (26.1926) \\
\hline \multirow{2}{*}{ High ROA } & $-0.4669 * * *$ & $51.2698 *$ \\
\hline & $(0.1724)$ & $(30.8588)$ \\
\hline \multirow{2}{*}{ Large scale } & $1.4164 * * *$ & $190.0042^{* * *}$ \\
\hline & $(0.2579)$ & (31.6312) \\
\hline \multirow{2}{*}{ High cost-to-income ratio } & 0.0260 & $47.4514 * *$ \\
\hline & $(0.1682)$ & $(20.3425)$ \\
\hline \multirow{2}{*}{ High capital adequacy ratio } & 0.1497 & -5.5449 \\
\hline & $(0.1243)$ & $(24.1752)$ \\
\hline \multirow{2}{*}{ High liquidity } & 0.2860 & 7.1754 \\
\hline & $(0.1867)$ & (18.9323) \\
\hline \multirow{2}{*}{ LDR } & 0.4729 & -43.3061 \\
\hline & $(1.5506)$ & (175.8789) \\
\hline \multirow{2}{*}{$\operatorname{lnM} 2$} & 4.7124 & 190.5962 \\
\hline & $(6.8316)$ & (366.0339) \\
\hline \multirow{2}{*}{$\operatorname{lnGDP}$} & 0.2805 & 299.7707 \\
\hline & $(5.6603)$ & (288.6044) \\
\hline \multirow{2}{*}{ Constant } & $-72.0058^{* *}$ & $-6,518.9082 * * *$ \\
\hline & $(34.8509)$ & $(2,183.1051)$ \\
\hline Observations & 418 & 418 \\
\hline Number of idc & 36 & 36 \\
\hline Likelihood-ratio test of rho $=0$ & 16.71 & \\
\hline Prob & $2.18 \mathrm{e}-05$ & \\
\hline Log likelihood & & -1153 \\
\hline Wald chi2 & & 17.49 \\
\hline
\end{tabular}

Source: WIND and CSMAR, and China Securitization Analysis database

Standard errors in parentheses, $* * * \mathrm{p}<0.01, * * \mathrm{p}<0.05, * \mathrm{p}<0.1$

To sum up, based on the five hypotheses proposed in this paper, the results of the empirical analysis support the hypotheses of profitability promotion and cost advantage exploitation. The incentives of liquidity demand, regulatory arbitrage, and risk transfer are not supported.

Compared with the result of Zhang et al.(2018), as shown in Table 3, both papers share the same incentive of cost advantage exploitation(Large scale). However, Zhang et al., (2018) concludes that the capital adequacy ratio (CAR) is a key incentive whilst this thesis concludes that the Profitability promotion (ROA) is the primary incentive. A possible explanation is that the capital source of China's commercial banks has improved after 2017. The main incentive for banks to pursue loan securitization is no longer to supplement capital, but to improve performance.

\subsection{The Tobit regression}

We use the Tobit regression method to further verify the influence of decision factors on the securitization amounts of commercial banks. As shown in Column(2) of Table 9, the coefficient of variable "Large scale" $(190.0042 * * *)$ and "High cost-to-income ratio" $\left(47.4514^{* * *}\right)$ are significant and positive, which further verify the results from the Logit regression in Column(1) of Table 9, and support the incentive hypotheses of Cost advantage exploitation and Profitability promotion. The direction of "High ROA" $\left(51.2698^{*}\right)$ is positive, contrary to the hypothesis. One explanation is that the amount of securitization is much smaller, which affects the accuracy of some Tobit regression coefficients. The data in Figure 2 and Figure 5 also support this explanation. 


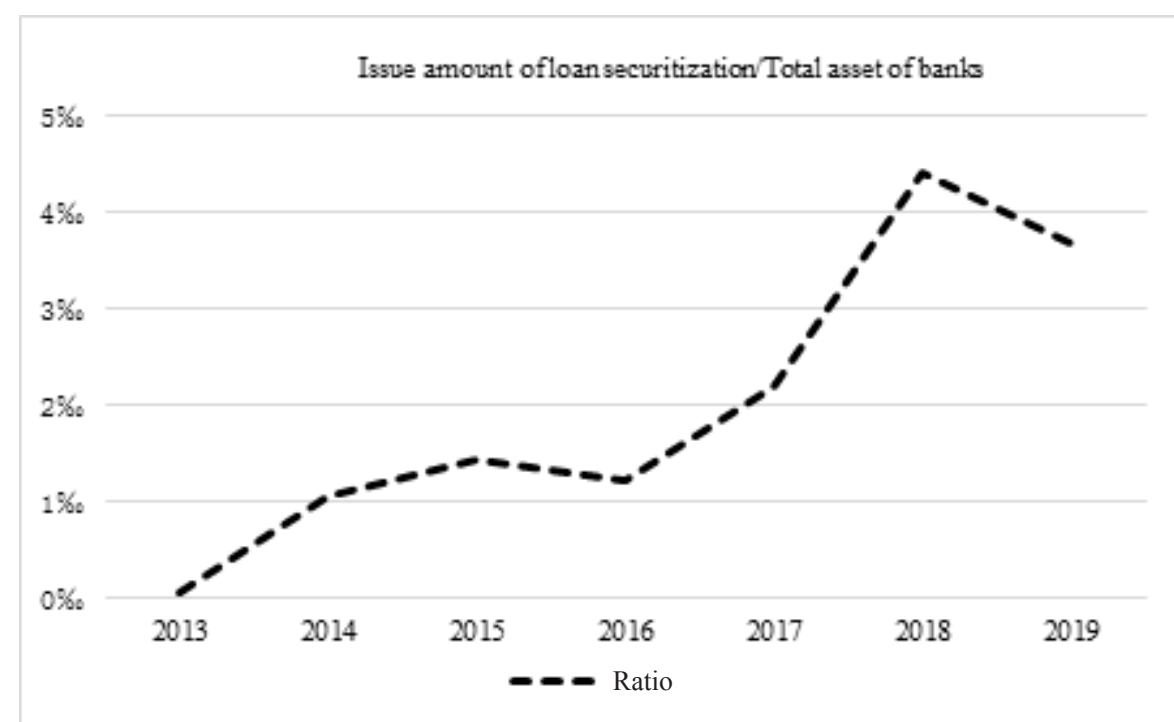

Figure 5. Ratio of the issuance of loan securitization to total assets of commercial banks

Source: WIND

\subsection{Robustness test}

Some special regression methods are used to test whether the results in Tables 8 are robust

\subsubsection{Subgroup regression}

According to the assets scale and time period of banks, the samples are divided into two groups, as shown in Table 10 Robust test A. Type I consists of fifteen national commercial banks, including six state-controlled banks and nine jointstock banks and Type II consists of twenty regional commercial banks. We use time period dummy variables to mark periods before and after the filing system. To remove the endogenous effects, we use one-year lagged explanatory variables to regress.

Table 10. Robustness test $\mathrm{A}$ - Grouping regression

\begin{tabular}{ccccc}
\hline & $(1)$ & $(2)$ & $(3)$ & $(4)$ \\
VARIABLES & Type I & Type II & $2012-2014$ & $2015-2019$ \\
& SEC & SEC & SEC & SEC \\
\hline High loan risk & -0.1971 & $0.6705^{* *}$ & 0.0881 & 0.4466 \\
High ROA & $(0.5255)$ & $(0.3234)$ & $(0.5553)$ & $(0.3381)$ \\
Large scale & -0.1612 & $-0.6807 * *$ & -0.3114 & $-0.5839^{*}$ \\
& $(0.3293)$ & $(0.2830)$ & $(0.2207)$ & $(0.3451)$ \\
High cost-to-income ratio & $1.3209 * *$ & -0.0828 & $0.7361 * *$ & $1.7286 * * *$ \\
& $(0.6202)$ & $(0.6594)$ & $(0.3682)$ & $(0.3434)$ \\
High capital adequacy ratio & $0.5523 *$ & $-0.6841 * *$ & -0.4419 & $0.4723 *$ \\
& $(0.2949)$ & $(0.3159)$ & $(0.2851)$ & $(0.2686)$ \\
High & 0.3275 & 0.1740 & $-0.6308 *$ & $0.2875 *$ \\
liquidity & $(0.2535)$ & $(0.4118)$ & $(0.3504)$ & $(0.1474)$ \\
& $0.8121^{* * *}$ & -0.1068 & 0.4570 & 0.3484 \\
LDR & $(0.2883)$ & $(0.2503)$ & $(0.3527)$ & $(0.2730)$ \\
& -0.8975 & 0.7882 & 0.3589 & 1.2601 \\
& $(2.9051)$ & $(1.9371)$ & $(2.3971)$ & $(1.6659)$ \\
& 11.8015 & 15.4403 & 0.3245 & 8.4184 \\
& $(12.2957)$ & $(16.5524)$ & $(7.9951)$ & $(10.0499)$ \\
\hline
\end{tabular}




\begin{tabular}{ccccc}
\hline & $(1)$ & $(2)$ & $(3)$ & $(4)$ \\
VARIABLES & Type I & Type II & $2012-2014$ & $2015-2019$ \\
& SEC & SEC & SEC & SEC \\
\hline lnGDP & -6.1546 & -4.2321 & $11.4185^{*}$ & -4.8111 \\
& $(10.5035)$ & $(9.3093)$ & $(5.8736)$ & $(6.7502)$ \\
Constant & $-93.1253^{*}$ & -172.8509 & $-140.8985^{*}$ & -62.9540 \\
Observations & $(54.5101)$ & $(243.2080)$ & $(81.0994)$ & $(67.9615)$ \\
Number of idc & 201 & 214 & 97 & 321 \\
Likelihood-ratio test of rho=0 & 16 & 20 & 34 & 36 \\
Prob & 4.894 & 10.10 & $1.53 \mathrm{e}-05$ & 20.69 \\
\hline
\end{tabular}

Source: WIND and CSMAR, and China Securitization Analysis database

Standard errors in parentheses, $* * * \mathrm{p}<0.01, * * \mathrm{p}<0.05, * \mathrm{p}<0.1$

The coefficient of variable "Large scale" in Column (1) and Column (2) are 1.3209** and -0.0828 respectively, and "High ROA's" coefficient is -0.1612 and $-0.6807^{* *}$, which suggests that only large banks (which own more loans) are incentivized to pursue cost advantage exploitation, and that small banks are more eager to improve their performance through loan securitization. Coefficients in Column (3) and (4) indicate that the incentive of cost advantage exploitation consistently works during the two periods and is not affected by the "Filing system". The incentive factors of performance promotion (variables of High ROA and High cost-to-income ratio) do not work (-0.3114 and -0.4419) until after the filing system $\left(-0.5839^{*}\right.$ and $\left.0.4723 *\right)$, suggesting that the implementation of the filing system results in the determinants of loan securitization of commercial banks arising from the commercial banks themselves instead of from supervision. The coefficient of High loan risk in Column (2) is $0.6705^{* *}$, signifying that small banks have an incentive to transfer risk through non-performing loan securitization.

The results of Table 10 verify that the estimation for bank's securitization determinants in Table 9 is fundamentally robust.

\subsubsection{Substitution variable regression}

The result in Table 9 does not support the incentive of risk transfer. We replace factor F1 (High loan risk, consistent with NPL and PC) with variables Z-score and DtD to test whether the result is robust. The estimation result is shown in Table 11. Variables Z-score and DtD are both used to measure a bank's overall risk positions. The difference is that Z-score represents the risks from the bank's accounting statement, and DtD represents the listed banks' overall risk exposures from the stock market.

Table 11. Robustness test B — Substitute for Risk variables

\begin{tabular}{ccc}
\hline VARIABLES & $(1)$ & $(2)$ \\
& SEC & SEC \\
\hline Z-score & $9.7690^{*}$ & \\
DtD & $(5.7798)$ & $0.0041 * *$ \\
& & $(0.0019)$ \\
High ROA & & -0.1829 \\
Large scale & -0.1375 & $(0.2335)$ \\
& $(0.2099)$ & $1.5184 * * *$ \\
High cost-to-income ratio & $1.2918^{* * *}$ & $(0.2779)$ \\
& $(0.1988)$ & 0.2193 \\
High capital adequacy ratio & 0.0617 & $(0.1967)$ \\
& $(0.1740)$ & $0.2905^{* *}$ \\
High liquidity & 0.1994 & $(0.1297)$ \\
& $(0.1537)$ & $0.5816^{* * *}$ \\
\hline
\end{tabular}




\begin{tabular}{ccc}
\hline \multirow{2}{*}{ VARIABLES } & $(1)$ & $(2)$ \\
& SEC & SEC \\
\hline LDR & $2.2643^{*}$ & $2.8173^{*}$ \\
& $(1.2989)$ & $(1.5488)$ \\
$\operatorname{lnM} 2$ & 4.8374 & 9.6041 \\
& $(6.4319)$ & $(6.0825)$ \\
$\operatorname{lnGDP}$ & -1.2227 & -4.4986 \\
& $(5.4511)$ & $(5.0458)$ \\
Constant & $-57.6198^{*}$ & $-85.1826^{* *}$ \\
Observations & $(30.9173)$ & $(33.4806)$ \\
Number of idc & 400 & 338 \\
Likelihood-ratio & 36 & 35 \\
test of rho $=0$ & 13.72 & 17.28 \\
Prob & 0.000106 & $1.61 \mathrm{e}-05$ \\
\hline
\end{tabular}

Source: WIND and CSMAR, and China Securitization Analysis database

Standard errors in parentheses, $* * * \mathrm{p}<0.01, * * \mathrm{p}<0.05, * \mathrm{p}<0.1$

The coefficient of Z-score is $9.7690^{*}$, indicating that the risk transfer incentive of commercial banks is weak, with the risks mainly arising from an accounting statement perspective. The coefficient of DtD is $0.0041 * *$, positive and significant, which means that banks with lower overall risk exposure to the stock market tend to pursue loan securitization. Moreover, in Column (2), considering the stock market risk, the coefficients of the variables "High capital adequacy ratio" and "High liquidity" are significant $\left(0.2905^{* *}\right.$ and $\left.0.5816^{* * *}\right)$ but the directions are not in line with the previous hypotheses which indicates that liquidity demand and regulatory arbitrage are not the motivations of loan securitization for listed commercial banks. The coefficient of variable Large scale is $1.2918^{* * *}$ and $1.5148^{* * *}$ in Column (1) and Column (2), showing that the incentive of Cost advantage exploitation is still significant.

To sum up, based on the result of Robustness test B in Table 11, the incentives of loan securitization of listed banks are cost advantage exploitation and risk transfer. The risks relate to the overall risk arising from the stock market rather than NPL.

\subsection{Sensitivity analysis}

In order to test the impact of bank loan securitization on China's financial reform, we designed the sensitivity analysis in Table12. According to the hypothesis proposed in 2.2.3, we select two variables, ICOR (incremental capital output rate, financial market level variable) and NIR (non-interest income, bank level variable). Loan securitization can activate the stock capital, reduce ICOR, and improve financial efficiency; Loan securitization can also transfer interest income off-balance sheet to increase non-interest income (NIR) in order to improve the income structure of commercial banks and reduce the overall risk of banks. In Table12, the explanatory variable is SEC. The results show that the coefficients of NIR and ICOR were -1.9301 and 0.0532 , and the directions are consistent with the previous hypothesis, but not significant. Further, it suggests that the role of China's loan securitization in financial reform is very limited. A potential reason is that the amount of loan securitization of commercial banks is not large enough and has little influence on the financial market. After grouping regression, NIR and ICOR, the coefficients are still not significant, which further verifies the aforementioned conclusion. The data in Figure 4 supports this explanation. Since 2013, the proportion of loan securitization issuances as a proportion of total bank assets have only reached $0.45 \%$ (in 2018 ).

\subsection{Estimating the relation between credit and deposit}

The results of literature research show that the relationship between deposit and credit growth is less intense after banks securitize (Loutskina, 2011; Almazan, 2015). Therefore, this paper intends to further test whether China's loan securitization can alleviate the dependence of bank loans on deposits, thus reducing the financial risk of the banking system. Table 13 is used to estimate the impact of securitization on bank loans on deposit dependence. The coefficient of deposit-growth in Column (1) and (6) are -0.0000 and $-0.2196^{* *}$ respectively, indicating that in general, the dependence of non- securitized banks on loans and deposits is significant. Securitization does reduce the dependence of bank loans on deposits and alleviates the credit risk of commercial banks. The coefficient of deposit-growth in Column (2) and (5) are $-0.4537 * *$ and $-0.4309 * *$, indicating that although loan securitization has been implemented, small banks and banks before 
the filing system still rely heavily on deposits. This could be because loan securitization of China's commercial banks is still in its infancy, and the securitization scale of small banks is too small to have a broader impact. In the un-securitizing banks, deposits are generally highly dependent on loans $\left(-0.2196^{* *}\right)$. Only the large banks have sufficient sources of deposits, and their dependence has decreased (-0.1267). For banks after 2015, the coefficient of deposit- growth is $0.2295^{* *}$, which is positive and significant, indicating that the current operation and management strategies of commercial banks include not only loan securitization, but also an active asset liability management strategy.

\section{Conclusions}

By the end of 2019, Chinese banks with large assets and low return on assets tended to securitize their loans. The empirical results of the Logit expression and Tobit expression confirm this conclusion, which is consistent with previous research findings. Through the regression test of the samples grouped by bank size and time period, the results are fundamentally robust. The robustness test of substituting risk variables shows that the motivation of loan securitization of listed commercial banks is cost advanced exploration and risk transfer. Compared with credit risk and statement level risk, listed commercial banks pay more attention to the overall risk from the stock market. Banks with lower risk tend to securitization. This finding verifies the robustness of results in Table 9. This study designs sensitivity analysis and loan deposit dependence estimation to test the impacts of asset securitization on China's financial reform. The results of the sensitivity analysis show that the direction of coefficients NIR and ICOR are consistent with the previous hypothesis, but not significant. Further, it shows that the effects of loan securitization on improving financial efficiency and optimizing bank income structure are not obvious. One possible explanation is that the issuances of loan securitization are small, and thus its influence on the banking system and financial market is not significant enough. The data in Figure 2 and Figure 4 also support this explanation. The estimation of the relationship between credit and deposit growth shows that deposit and credit growth is less intense after banks are able to securitize (the coefficients of Deposit-growth in Column (1) (3)(4) are -0.0000); But the effect is limited in small banks (the coefficient is $-0.4309 * * *$ ). This could be due to the fact that small banks have limited sources of funds and their loans are highly dependent on deposits. Although there are some loan securitization operations, the effect is very limited. Besides, banks with small asset amounts are not popular in China's asset securitization market.

To sum up, China's loan securitization market welcome large banks with lower risk rather than small banks. The external policy driven factor is being replaced by the internal performance demand after the filing system and the maturity of asset securitization market. Default risks of listed banks themselves rather than that of loan customers affect bank's loan securitization decision more. The spread business of indirect financing is still the most profitable and safest investment choice in China's financial market. Loan securitization has indeed improved the credit-deposit relationship of banks but has not played a significant role in improving the income structure of commercial banks. China's financial reform is a huge, complex and far-reaching project, which requires the cooperation and efforts of the government and financial market in an all-round way. The loan securitization market should be developed continuously and rapidly, which is of great implications to China's financial reform. 


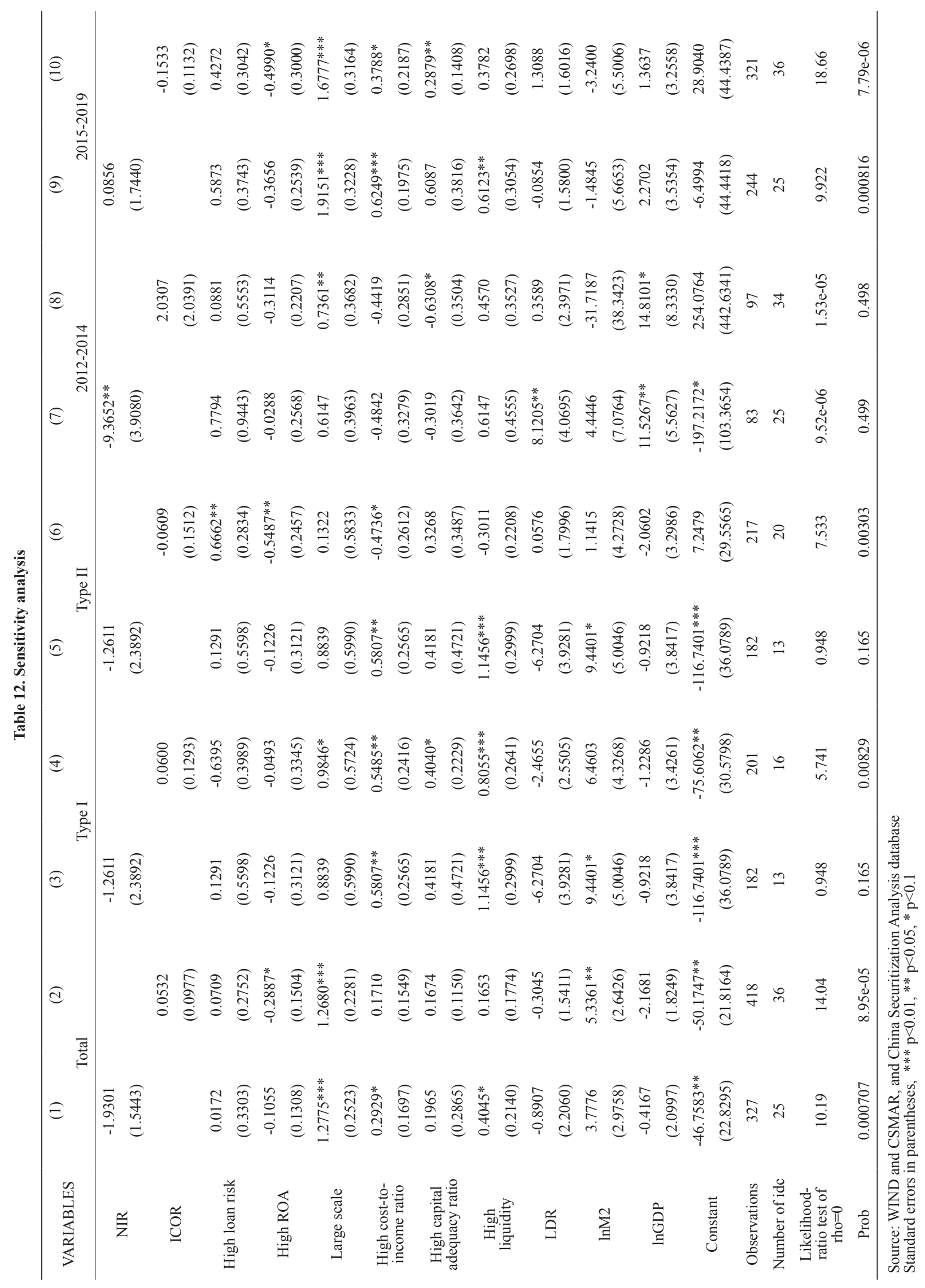




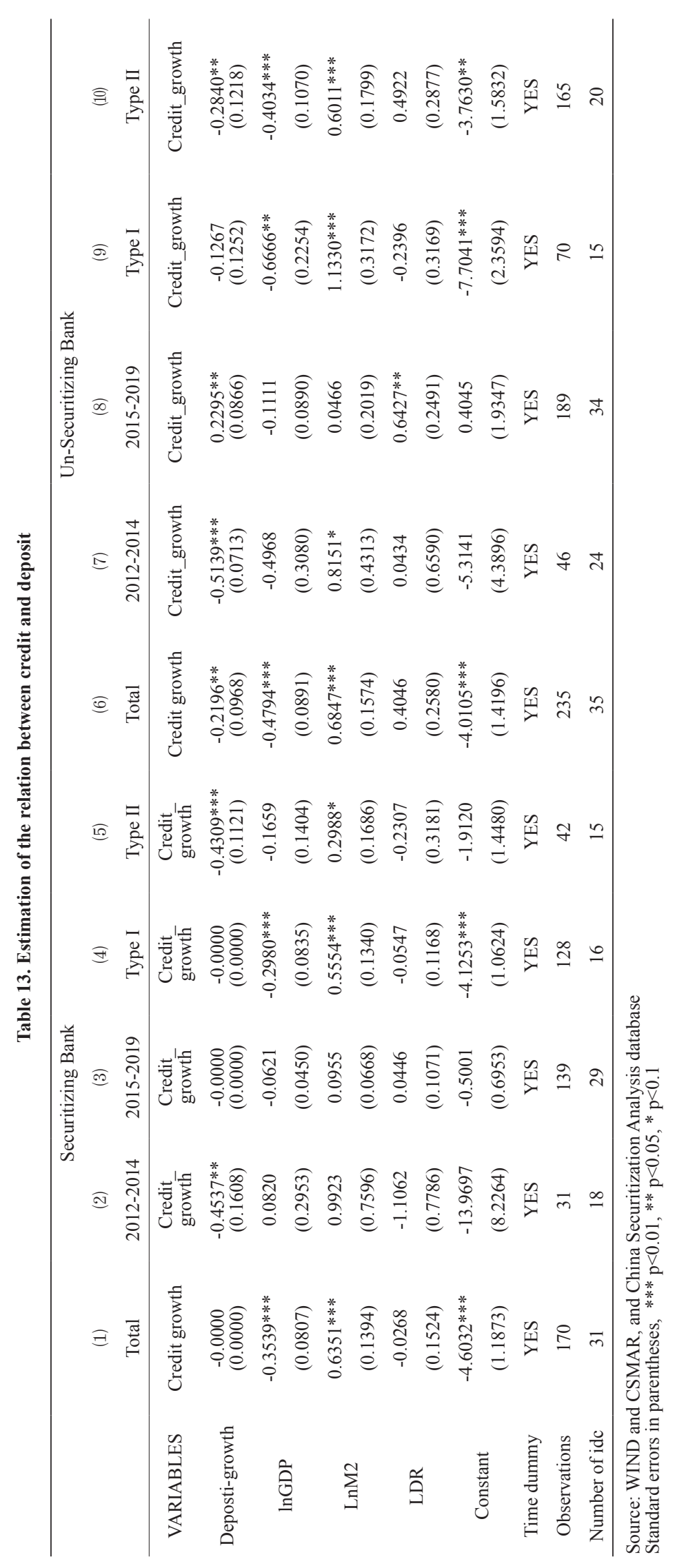




\section{References}

[1] Huang Yiping,Yin Jianfeng,Zhang Bin, et al. The Road Map of China's Financial Reform: Building a Modern Financial System. Beijing: CITIC Publishing Group; 2018.

[2] Shen Bingxi. Asset Securitization and Financial Reform. Journal of Financial Research. 2006; 315(9): 104-117.

[3] Wu Qing. Asset Securitization of Commercial Banks and China's Financial Reform. Studies of International Finance. 1999; (12): 61-66.

[4] Affinito, M., and Tagliaferri, E. Why Do (or Did?) Banks Securitize Their Loans? Evidence from Italy. Journal of Finance. 2010; 6(4): 189-203.

[5] Agarwal, S., Chang, Y., and Yavas, A. Adverse Selection in Mortgage Securitization. Journal of Finance. 2012; 105(3): 640-661.

[6] Almazan, A., Martin-Oliver, A., and Saurina, J.Securitization and Banks' Capital Structure. Corporate Finance. 2015; 4(2): 206-238.

[7] Ambrose, B., LaCour-Little, M., and Sanders, A. Does Regulatory Capital Arbitrage, Reputation, or Asymmetric Information Drive Securitization? Journal of Finance. 2005; 28: 113-134.

[8] Altman, E.I., (2000). Predicting Financial Distress of Companies: Revisiting the Z-score and Zeta Model. working paper. New York University

[9] Bensalah, N., and Fedhila, H. What Explains the Recourse of U.S. Commercial Banks to Securitization? Review of Accounting and Finance. 2016; 15(3): 317-329.

[10] Bertay Ata Can,Di Gong and Wolf Wagner. Securitization and Economic Activity: The Credit Compositionchannel. Journal of Financial Stability. 2017; 28: 225-239.

[11] Calem, P.S., and LaCour-Little, M. Risk-based Capital Requirements for Mortgage Loans. Journal of Banking \& Finance. 2004; 28(3): 647-673.

[12] Cardone-Riportella,C., Samaniego-Medina,R., and Trujillo-Ponce, A. What Drives Bank Securitization? The Spanish Experience. Journal of Banking \& Finance. 2010; 34(11): 2639-2651.

[13] Casu Barbara, Andrew Clare and Anna Sarkisyan, et al. Securitization and Bank Performance. Journal of Money, Credit and Banking. 2013; 45(8): 1617-1658.

[14] Cumming, C. The Economics of Securitization. Quart. Rev. 1987: 11-23.

[15] Chen Weizu, Chi-Chun Liu and Stephen G.Ryan. Characteristics of Securitizations that Determine Issuers' Retention of the Risks of the Securitized Assets. The Accounting Review. 2008; 83(5): 1181-1215.

[16] DeMarzo Peter, Darrell Duffie. A Liquidity-based Model of Security Design. Econometrica. 1999; 67(1): 65-99.

[17] DeMarzo Peter M. The Pooling and Tranching of Securities: a Model of Informed Intermediation. The Review of Financial Studies. 2005; 18(1): 1-35.

[18] Farruggio, C., and Uhde, A. Determinants of Loan Securitization in European Banking. Journal of Banking \& Finance. 2015; 56: 12-27.

[19] Greenbaum Stuart I. and Anjan V. Thakor. Bank Funding Modes: Securitization versus Deposits. Journal of Banking and Finance. 1987; 11(3): 379-401.

[20] Guo, G., and Wu, H. A Study on Risk Retention Regulation in Asset Securitization Process. Journal of Banking \& Finance. 2014; 45: 61-71.

[21] He Jie, Jun Qian and Philip E. Strahan. Are All Ratings Created Equal? The Impact of Issuer Size on the Pricing of Mortgage-Backed Securities. The Journal of Finance. 2012; (6): 2097-2137.

[22] Landsman Wayne R., Kenneth V. Peasnell, Catherine Shakespeare (2008), Are Assets Securitizations Sales or Loans? Accounting Review.

[23] Loutskina, E. The Role of Securitization in Bank Liquidity and Funding Management. Journal of Financial Economics. 2011; 100: 663-684.

[24] Minton B., Sanders A., Strahan P. E. (2004) Securitization by Banks and Finance Companies: Efficient Financial Contracting or Regulatory Arbitrage? Working Paper Series 2004-25, Ohio State University, Charles A. Dice Center for Research in Financial Economics.

[25] Martin-Oliver A., Saurina, J. Why Do Banks Securitize Assets? In: XV Spanish Finance Forum Conference Proceedings. Palma de Mallorca: Spanish Finance Association ; 2007.

[26] Merton R. C. On the Pricing of Corporate Debt: The Risk Structure of Interest Rates. The Journal of Finance. 1974; 29(2): 449-470.

[27] Yamazaki K. (2005) What Makes Asset Securitization "Inefficient"? Working Paper, bepress Legal Series. Available from: https://law.bepress.com/expresso/eps/603/

[28] Zhang J, Yin Y, Zhang L. Determinants of Loan Securitization in Chinese Banking: Cost-benefit-based Analysis. Pacific-Basin Finance Journal. 2018; 1-19. 


\section{Appendix}

\section{Calculation of the Distance-to-Default (DtD)}

In line with Merton (1974), the market value of a bank's equity capital can be modeled as a contingent claim on the residual value of its assets. Therefore, in case a bank defaults, the bank's shareholders receive no compensation for their investment if the market value of the bank's assets falls below the market value of the bank's liabilities. In contrast, if the market value of the bank's assets exceeds the market value of liabilities, the bank's shareholders obtain the difference between the market value of assets and liabilities. Consequently, the contingent claim on the residual value of a bank's assets can be modeled as a call option on the underlying bank using standard option-pricing models.

The distance from the default point $(\mathrm{VA}=\mathrm{DB})$ can be expressed as follows:

$$
D=\ln V_{A}^{T}-\ln D B=\ln V_{A}+\left(\mu-\frac{1}{2} \sigma_{A}^{2}\right) T+\sigma_{A} \sqrt{T} \varepsilon-\ln D B
$$

the Distance-to-Default is designed to indicate the number of standard deviations that the bank is away from the default point within a given time horizon. The unobservable parameters $V_{A}$ and $\sigma_{A}$ can be calculated from the observable market value of equity capital $\left(V_{E}\right)$ as well as the standard deviation of share price returns $\left(\sigma_{E}\right)$ using Ito's lemma.

$$
\begin{aligned}
& D t D \equiv \frac{D}{\sigma_{A} \sqrt{T}}-\varepsilon=\frac{\ln \left(\frac{V_{A}}{D_{B}}\right)+\left(\mu-\frac{1}{2} \sigma_{A}^{2}\right) T}{\sigma_{A} \sqrt{T}} \\
& V_{E}=V_{A} N\left(d_{1}\right)-D B e^{-r T} N\left(d_{2}\right) \\
& \sigma_{E}=N\left(d_{1}\right) \frac{V_{A}}{V_{E}} \sigma_{A} \\
& d_{1} \equiv \frac{\ln \left(\frac{V_{A}}{D_{B}}\right)+\left(\mu+\frac{1}{2} \sigma_{A}^{2}\right) T}{\sigma_{A} \sqrt{T}}=\frac{\ln \left(V_{A} \exp \left(\left(\mu+\frac{1}{2} \sigma_{A}^{2}\right) T\right)\right)-\ln D_{B}}{\sigma_{A} \sqrt{T}}=\frac{\ln \left(\frac{V_{A}}{D_{B}}\right)+\left(\mu-\frac{1}{2} \sigma_{A}^{2}\right) T}{\sigma_{A} \sqrt{T}} \\
& d_{2} \equiv d_{1}-\sigma_{A} \sqrt{T}=\frac{\ln \left(V_{A} \exp \left(\mu-\frac{1}{2} \sigma_{A}^{2}\right) T\right)}{\sigma_{A} \sqrt{T}}-\ln D_{B}
\end{aligned}
$$

\section{Calculation of the $\mathbf{Z}$-score}

We use a modified version of the Z-score that builds upon the work of Altman (2000), and is calculated as follows:

$$
Z_{i, t} \equiv \frac{\mu_{i, t}-X_{i, t}}{\sigma_{i, t}}
$$

We calculate the Z-score for each bank $\mathrm{i}$ in each single year $\mathrm{t}$ where $\mu$ is the return on average assets before taxes (ROAA), $\mathrm{X}$ is a bank's equity capital as a percent of total assets and $\sigma$ equals the standard deviation of the ROAA. A lower $\mathrm{Z}$-score indicates a higher probability of insolvency risk and vice versa. 